\title{
Synbiotic Goat Milk Kefir Lowered Peroxisome Proliferator Activated Receptor Gamma (PPARY) Gene Expression in Rat Adipose and Liver Tissue
}

Nurliyani Nurliyani ( $\square$ nurliyani@ugm.ac.id)

UGM: Universitas Gadjah Mada

Eni Harmayani

Universitas Gadjah Mada

Sunarti Sunarti

Universitas Gadjah Mada

\section{Research}

Keywords: $\beta$-cells, FFA, HbA1c, PPARY, Synbiotic kefir, TNFa

Posted Date: February 11th, 2021

DOl: https://doi.org/10.21203/rs.3.rs-159681/v1

License: (c) (i) This work is licensed under a Creative Commons Attribution 4.0 International License.

Read Full License 


\section{Abstract \\ Background}

Kefir is a fermented milk product containing bacteria and yeast, whereas glucomannan from porang (Amorphophallus oncophyllus) tuber is known as a prebiotic in vivo. Diets with a high fat and high sugar will stimulate metabolic syndrome associated with changes in gene expression including peroxisome proliferator activated receptor gamma (PPARY). The purpose of this study was to determine the effect of goat milk kefir enriched with porang glucomannan (synbiotic kefir) and goat milk kefir without glucomannan (probiotic kefir) on blood glucose, hemoglobin A1c (HbA1c), free fatty acid (FFA), tumor necrosis factor alpha (TNF-a), gene expression of peroxisome proliferator activated receptor gamma (PPARY), and insulin-producing cells in rats fed a high-fat and high-fructose (HFHF) diet.

\section{Methods}

Male Sprague Dawley rats 8-12 weeks old $(n=30)$ treated with HFHF diets for two weeks, and then divided into five dietary groups (each group consisted of 6 rats): 1) normal control (received a standard diet only); 2) rats fed HFHF; 3) rats fed HFHF + probiotic kefir; 4) rats fed HFHF + synbiotic kefir; and 5) rats fed HFHF + simvastatin. The dose of kefir was $3.6 \mathrm{~mL} / 200 \mathrm{~g}$ body weight/day and simvastatin was $0.72 \mathrm{mg} /$ day. All of these treatments were carried out for 4 weeks.

\section{Results}

There were no significant differences in plasma blood glucose in HFHF rats after and before treatment, but decreased in plasma HbA1c and TNFa $(p<0.05)$ and inhibited the increase of FFA in rats after synbiotic kefir treatment (paired-samples t-test). Probiotic and synbiotic kefir decreased the gene expression of PPARy2 $(p<0.05)$ in both of adipose and liver tissue in HFHF rats but had no effect on the total number of Langerhans islets and insulin-producing cells (one way ANOVA).

\section{Conclusions}

Synbiotic kefir could ameliorate the health of rats fed HFHF diet through decreasing $\mathrm{HbA} 1 \mathrm{c}$, TNFa, and PPARY2 gene expression and preventing an increase in FFA. The results indicate that goat milk synbiotic kefir potentially improve metabolic syndrome.

\section{Introduction}

Limited physical activity and enhanced exposure to unhealthy foods that are energy-dense ("obesogenic" environment) cause increased obesity. The prevalence of obesity in the last decade is becoming increasingly common and becoming a major nutritional problem throughout the world. The risk factors in 
development of obesity are also influenced by genetic factors and physiological problems. Obesity may negatively affect on the development of insulin resistance, type-2 diabetes and metabolic syndrome. Because of the limitations of obesity and metabolic syndrome therapy, prevention strategies are needed [1].

Prevention and treatment of metabolic syndrome can be performed both pharmacologically and nonpharmacologically. Functional food affecting health benefits can be derived from animal or plant sources. Metabolic syndrome can be treated with various approaches, including targeting lipoproteins, blood pressure or anthropometric index. Peroxisome proliferator-activated receptors (PPARs) are play a role in the metabolic control of lipid and lipoprotein levels, i.e. triglycerides (TGs), blood glucose, and abdominal adiposity [2]. PPARy is abundantly expressed in adipose tissue and, to a lesser extent, in macrophages and other cell types, and regulates adipogenesis, lipid storage, and glucose homeostasis [3]. PPARy2 is specific for adipose tissue, where it plays a pivotal role in adipogenesis and is an important mediator of insulin sensitivity [4] and a more potent transcription activator [5].

In reducing obesity in mice induced by a high fat diet, a probiotic kefir plays an important role in weight loss and reduce the epididymal fat layer and the diameter of adipocytes. The reduction in gene expression associated with adipogenesis and lipogenesis and also a lowered the levels of proinflammatory markers in epididymal fat has confirmed the role of kefir [6]. Recent studies show that properties of kefir and isolated microorganisms from it have the potential to be anti-atherosclerotic through an enhance in anti-inflammatory cytokines and reduce pro-inflammatory responses [7].

Porang (Amorphophallus oncophyllus) is a tuber locally that is often found in Indonesian forests, and it is being cultivated. Similar to Amorphophallus konjac, porang tuber contains glucomannan and has been shown to be a prebiotic in vivo [8], that selectively enhances the growth of probiotic bacteria such as lactobacilli and bifidobacterial [9]. Glucomannan is a water-soluble dietary fiber that can improve blood sugar, blood fat concentration, and weight management and has other health benefits. Subject with metabolic syndrome will be comfortable consuming glucomannan as a substitute for main carbohydrates, in the form of noodles given 4 weeks can reduce the risk of metabolic syndrome and reduce oxidative stress [10].

The purpose of this study was to evaluate the effect of synbiotic kefir (goat milk kefir with additional glucomannan from porang) and probiotic kefir ( goat milk kefir without porang glucomannan) on gene expression associated with the metabolic regulation of lipids and blood glucose, i.e. PPARY in adipose and liver tissue in rats fed a high-fat and high-fructose diet.

\section{Materials And Methods}

\section{Kefir preparation}

Synbiotic kefir made from a mixture of goat milk, porang glucomannan (as prebiotic), whey protein concentrate (WPC) and kefir grain. Glucomannan from porang tuber was obtained from the Faculty of 
Agrigultural Technology, Universitas Gadjah Mada, Yogyakarta, Indonesia. Fresh goat milk was originated from Ettawah Crossbred goats in Yogyakarta, Indonesia. Whey protein concentrate (WPC) was obtained from the Sari Husada Milk industry in Yogyakarta, Indonesia. Kefir grain was purchased from a local supplier in Yogyakarta.

The methods of synbiotic kefir preparation was done according to [11] with slight modification. Goat milk, $0.1 \%$ whey protein concentrate (WPC), and $0.3 \%$ porang glucomannan were mixed, pasteurized at $75^{\circ} \mathrm{C}$ for $15 \mathrm{~min}$, and cooled at room temperature. Kefir grains (2\%) were inoculated into pasteurized milk and incubated at room temperature for $18 \mathrm{~h}$. After incubation, the kefir was filtered to separate kefir grains. Probiotics kefir were prepared with goat milk, WPC and kefir grain without glucomannan. Synbiotics kefir were prepared by addition of glucomannan into probiotics kefir.

\section{Animal experiments}

Male Sprague Dawley rats 8-12 weeks old were divided into 5 groups (each group consisted of 6 rats): 1) normal control (negative control rats) that received a standard diet only, 2) rats fed high-fat/high-fructose (HFHF) (positive control), 3) rats fed HFHF + probiotic kefir, 4) rats fed HFHF + synbiotic kefir, and 5) rats fed HFHF+ simvastatin. The dose of kefir was $3.6 \mathrm{~mL} / 200 \mathrm{~g}$ body weight/day for 4 weeks. The dose of simvastatin was $0.72 \mathrm{mg} /$ day.

The rats were adapted with standard diet AIN-93 for 1 week and then treated with a high fat and high fructose diet for 2 weeks. The rats were then divided into 5 groups as described above. A high-fat and high-fructose diet was administered until the end of the experiment (4 weeks). The composition of the standard diet and high-fat and high-fructose diet were prepared according to [12,13] with slight modification. All treatments which given to animal experiments in this study were already approved by the Medical and Health Research Ethics Committee (MHREC), Faculty of Medicine Universitas Gadjah Mada, Indonesia (Approval number: KE/FK/95/EC/2015).

\section{Table 1 Formulation of standard (AIN-93) and high fat/high fructose diets}

\begin{tabular}{clll}
\hline No. & Ingredient $(\mathrm{g} / \mathrm{kg})$ & AIN-93M* & High fat + fructose** \\
\hline 1 & Fructose & - & 321,6 \\
2 & Casein & 140,00 & 190,25 \\
3 & Condensed milk & - & 158 \\
4 & Soy bean oil & 40,00 & 20 \\
5 & Tallow (beef fat) & - & 185 \\
6 & Fiber/ alpha cel & 50,00 & 25 \\
7 & Wheat bran & - & 54,15 \\
8 & Mineral Mix & 35,00 & 35 \\
9 & Vitamin Mix & 10,00 & 10 \\
10 & DL-Methionine & 1,80 & 1,8 \\
11 & Cholin Chloride & 2,50 & 2,5 \\
12 & Corn starch & 620,70 & - \\
13 & Sucrose & 100,00 & - \\
\hline
\end{tabular}


*Reeves (1993)， ～** de Castro et al. (2013)

Fasting plasma blood glucose was measured by an enzymatic photometric test using the glucose oxidase phenol 4-aminoantipyrine peroxidase (GPO-PAP) method according to the instructions in the kit (Dia Sys, Holzheim-Germany). Glycosylated hemoglobin (HbA1c) analysis was performed according to the instructions in the Rat HbA1c ELISA Kit (ELabScience, Wuhan, China). Analysis of plasma FFA was performed according to the instructions of the Rat FFA ELISA Kit (Qayee-Bio, Shanghai, China). Plasma TNFa was analyzed according to the instructions in rat-specific ELISA kits for the measurement of TNFa (eBioscience, Bender MedSystem, Vienna, Austria).

\section{Gene expression analysis}

PPARy2 gene expression was analyzed through 4 stages: 1) isolation of RNA from white adipose tissue and liver tissue, 2) reverse transcription from RNA to CDNA using reverse transcriptase enzyme, 3) cDNA amplification by PCR and 4) quantification and detection of cDNA products with real-time PCR.

Total RNA was extracted from adipose tissue using TRIzol reagent, and mRNA levels were analyzed by real-time polymerase chain reaction (PCR). Reverse transcription of total RNA was performed using the First Strand cDNA Synthesis Kit (Roche) Transcriptor. Transcription reagents to produce cDNA. Real-time PCR was carried out in a mixture (final volume $20 \mu \mathrm{L}$ ) containing $2 \mu \mathrm{L}$ cDNA (DNA template), $10 \mu \mathrm{L}$ Evagreen, $1 \mu \mathrm{L} \mathrm{GAPDH}, 1 \mu \mathrm{L}$ GAPDH, and $6 \mu \mathrm{L}$ RNAse-free water. Likewise for Forword and Reverse PPARY2 with additional reagents totaling $20 \mu \mathrm{L}$ as well. The amount of mRNA was calculated as the ratio to the value of glyceraldehyde-3-phosphate dehydrogenase (GADPH) in each cDNA sample. The primary nucleotide sequences used to detect each mRNA were designed using Primary Express Software according to the sequences available in the GenBank database. The primary nucleotide sequences are shown in Table 2 [14].

Table 2 Primer nucleotide sequences for real-time PCR

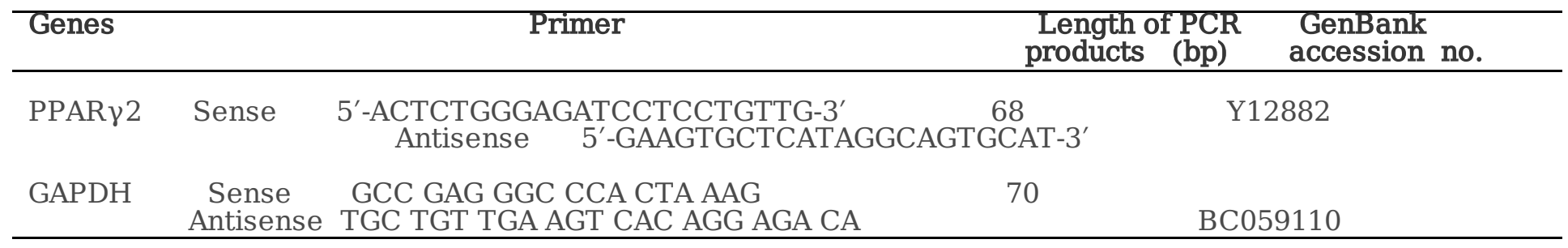

Optimization of cDNA amplification products was performed using conventional PCR with a program at a temperature of $95^{\circ} \mathrm{C}$ for 5 minutes, $95^{\circ} \mathrm{C}$ for 1 minute, $58^{\circ} \mathrm{C}$ for 1 minute, and $72^{\circ} \mathrm{C}$ for 1 minute with $34 \mathrm{x}$ cycles. The temperature was maintained at $72^{\circ} \mathrm{C}$ for 5 minutes and $12^{\circ} \mathrm{C}$ for 5 minutes. The optimization program for real-time (RT)-PCR was at a temperature of $95^{\circ} \mathrm{C}$ for 5 minutes, $95^{\circ} \mathrm{C}$ for 1 minute, $60^{\circ} \mathrm{C}$ for 30 seconds and $72^{\circ} \mathrm{C}$ for 1 minute with $39 x$ cycles. The melt curve was maintained at $65-95^{\circ} \mathrm{C}$ for 5 seconds, and then the plate was read. The average change in the level of gene expression $\left(2^{-\triangle \Delta C T}\right)$ PPARgamma-2 was analyzed according to [15]. 


\section{Immunohistochemistry of insulin-producing cells}

Mouse monoclonal insulin primary antibody (Abcam, [K36aC10] ab6995, Cambridge, USA) was used in this analysis. Pancreatic tissue slides were counterstained with hematoxylin, mounted with coverslips and observed under a light microscope. The number of Langerhans islets and insulin-producing cells were calculated using a colony counter and then documented by an Opti Lab (SOP No A-007) microscope.

\section{Statistical analysis}

Data from this analysis are presented as the mean \pm standard deviation. Data of blood plasma analysis before and after treatments including fasting blood glucose, HbA1c, FFA, and TNFa. The difference between the mean of blood plasma analysis before and after treatments was analyzed by pairedsamples t-test. One-way ANOVA followed by Duncan's multiple range test (DMRT) was used for statistical analyses of the gene expression of PPAR, total number of Langerhans islets and insulin-producing cells (p-values of less than 0.05 indicated significant differences). Statistical analyses were performed using SPSS version 17 software.

\section{Results}

\section{Blood glucose}

The average fasting blood glucose levels in rats fed a high fructose and high fat diet before and after being treated with probiotic kefir, synbiotic kefir and simvastatin are shown in Table 3.

Table 3 The average blood glucose in rats before and after treatments

\begin{tabular}{lcc}
\hline Treatments & \multicolumn{2}{c}{ Fasting blood glucose $(\mathrm{mg} /$ dL) } \\
\cline { 2 - 3 } & Before treatment & After treatment \\
\hline Normal control & $94,11 \pm 19,02^{\mathrm{a}}$ & $95,51 \pm 21,10^{\mathrm{a}}$ \\
HFHF & $104.05 \pm 12,93^{\mathrm{a}}$ & $118.90 \pm 11,33^{\mathrm{a}}$ \\
HFHF+ probiotic kefir & $112.81 \pm 9,54^{\mathrm{a}}$ & $114.34 \pm 18,81^{\mathrm{a}}$ \\
HFHF+synbiotic kefir & $116.98 \pm 6,76^{\mathrm{a}}$ & $105.08 \pm 11,93^{\mathrm{a}}$ \\
HFHF+simvastatin & $221,37 \pm 6,76^{\mathrm{a}}$ & $82,35 \pm 11,93^{\mathrm{b}}$ \\
\hline
\end{tabular}

Different letters in the same row indicate significant differences $(\mathrm{P}<0,05)$

Table 3 shows that in negative controls (normal rats, only receiving standard diet), blood glucose levels were still within the normal glucose range, and there was no difference before and after treatment. Rats that only received high-fructose and high-fat feed (positive control) showed higher glucose levels after being given the diet for 5 weeks (after treatment) compared to before treatment, although not significantly. Goat milk kefir enriched with porang glucomannan could reduce blood glucose levels, but the decrease was not significant, which was only $11.9 \mathrm{mg} / \mathrm{dL}$. Simvastatin treatment significantly reduced blood glucose levels in rats fed a HFHF diet, which was approximately $139.02 \mathrm{mg} / \mathrm{dL}$. 
Based on Table 4, HbA1c levels in rats after treatment with synbiotic kefir were lower $(p<0.05)$ than those before treatment. However, other groups of rats, including those who received probiotic kefir treatment, did not show any significant difference before and after treatment.

Table 4 The average HbA1c in rats before and after treatment

\begin{tabular}{|c|c|c|}
\hline \multirow{2}{*}{ Treatments } & \multicolumn{2}{|c|}{ HbA1c (ng/mL) } \\
\hline & Before treatment & After treatment \\
\hline Normal control & $21,47 \pm 5,18^{\mathrm{a}}$ & $24,33 \pm 3,35^{a}$ \\
\hline HFHF & $24,98 \pm 2,92^{\mathrm{a}}$ & $26,45 \pm 4,60^{\mathrm{a}}$ \\
\hline HFHF+probiotic kefir & $26,02 \pm 4,79^{a}$ & $35,44 \pm 18,99^{a}$ \\
\hline HFHF+synbiotic kefir & $28,89 \pm 4,12^{\mathrm{a}}$ & $23,56 \pm 3,47^{b}$ \\
\hline HFHF+simvastatin & $22,72 \pm 4,64^{\mathrm{a}}$ & $33,61 \pm 16,45^{\mathrm{a}}$ \\
\hline
\end{tabular}

Different letters in the same row indicate significant differences $(P<0,05)$

\section{Free fatty acid (FFA)}

Table 5 shows that the average plasma FFA levels in rats after various treatments were higher $(p<0.05)$ in all groups of rats than before treatment, although the increase in FFA after kefir treatment was not significant.

Table 5 The average plasma FFA in rats before and after various treatments

\begin{tabular}{lll}
\hline \multirow{2}{*}{ Treatments } & \multicolumn{2}{c}{ FFA (ng/mL) } \\
\cline { 2 - 3 } & Before treatment & After treatment \\
\hline Normal control & $54.20 \pm 5.47^{\mathrm{a}}$ & $61.41 \pm 2.19^{\mathrm{b}}$ \\
HFHF & $60.15 \pm 4.66^{\mathrm{a}}$ & $63.25 \pm 3.74^{\mathrm{b}}$ \\
HFHF+probiotic kefir & $59.92 \pm 2.74^{\mathrm{a}}$ & $62.24 \pm 2.84^{\mathrm{a}}$ \\
HFHF+synbiotic kefir & $59.59 \pm 4.49^{\mathrm{a}}$ & $62.85 \pm 4.13^{\mathrm{a}}$ \\
HFHF+simvastatin & $54.04 \pm 8.32^{\mathrm{a}}$ & $61.21 \pm 6.21^{\mathrm{b}}$ \\
\hline
\end{tabular}

Different letters in the same row indicate significant differences $(P<0,05)$

\section{Tumor necrosis factor alpha (TNFa)}

Based on Table 4, there was no decrease in TNFa levels in rats after various treatments, except in rats treated with synbiotic kefir.

Table 6 The average plasma TNF $\alpha$ in rats before and after treatment

\begin{tabular}{|c|c|c|}
\hline \multirow[b]{2}{*}{ Treatments } & \multicolumn{2}{|c|}{ TNF $\alpha(p g / m L)$} \\
\hline & Before treatment & After treatment \\
\hline Normal control & $157.66 \pm 15.71^{a}$ & $166.66 \pm 20.84^{\mathrm{a}}$ \\
\hline HFHF & $170.33 \pm 23.54^{\mathrm{a}}$ & $271.33 \pm 167.86^{\mathrm{a}}$ \\
\hline HFHF+probiotic kefir & $159.33 \pm 14.06^{\mathrm{a}}$ & $208.00 \pm 44.68^{b}$ \\
\hline HFHF+synbiotic kefir & $176.50 \pm 13.79^{a}$ & $155.00 \pm 6.63^{b}$ \\
\hline HFHF+simvastatin & $169.33 \pm 11.07^{\mathrm{a}}$ & $192.33 \pm 50.49^{\mathrm{a}}$ \\
\hline
\end{tabular}

Different letters in the same row indicate significant differences $(P<0,05)$ 
The average change in the level of PPARy2 gene expression $\left(2^{-\Delta \Delta C T}\right)$ in white adipose tissue from HFHF rats treated with kefir with or without glucomannan was not significantly different from that of rats treated with simvastatin. The rats treated with kefir had a lower change in PPAR $\mathrm{Y} 2$ gene expression than HFHF rats without kefir $(p<0.05)$ (Table 7$)$.

Table 7 Average relative expression of PPARy2 genes in white adipose tissue from rats receiving various treatments

\begin{tabular}{|c|c|}
\hline & PPAR y2 gene expression \\
\hline Perlakuan & $2^{-\Delta \Delta \mathrm{CT}}$ \\
\hline HFHF & $-3,74 \pm 1,08^{a}-0,67 \pm 1,08^{a} 1,96 \pm 1,24^{a}$ \\
\hline $\mathrm{HFHF}+$ probiotic kefir & $-2,41 \pm 1,12^{\mathrm{ab}} 0,65 \pm 1,12^{\mathrm{ab}} 0,80 \pm 0,55^{\mathrm{b}}$ \\
\hline HFHF+ synbiotic kefir & $-1,00 \pm 0,94^{b c} 2,06 \pm 0,94^{b c} 0,29 \pm 0,23^{b}$ \\
\hline HFHF+ simvastatin & $-2,22 \pm 1,12^{\mathrm{c}} \quad 0,66 \pm 1,12^{\mathrm{c}} \quad 0,70 \pm 0,52^{\mathrm{b}}$ \\
\hline
\end{tabular}

Different letters in the same column indicate significant differences $(p<0,05)$

Normal control rats had an average $\Delta$ CT of -3.07 , an average $\Delta \Delta C T$ of 0.00 and an average of changes in the gene expression of PPAR y2 $\left(2^{-\Delta \Delta \mathrm{CT}}\right)$ of 1.00 .

Based on Table 8, the pattern of the changes in the expression of PPARy2 genes in liver tissue was similar to that of white adipose tissue, in which rats treated with kefir added or without glucomannan showed lower changes in gene expression $(p<0.05)$ compared to rats without kefir treatment. Likewise, the simvastatin-treated rats also had lower changes in PPARy2 gene expression $(p<0.05)$ than the HFHF rats.

Table 8 Average relative expression of PPAR $\gamma 2$ genes in liver tissue from rats receiving various treatments

\begin{tabular}{|c|c|c|c|}
\hline \multirow{2}{*}{ Treatments } & \multicolumn{3}{|c|}{ PPAR 2 gene expression } \\
\hline & $\Delta \mathrm{CT}$ & $\Delta \Delta \mathrm{CT}$ & $2^{-\Delta \Delta \mathrm{CT}}$ \\
\hline HFHF & $0,00 \pm 1,59^{a}$ & $-6,28 \pm 1,59^{a}$ & $\overline{123,46 \pm 120,56}{ }^{a}$ \\
\hline $\mathrm{HFHF}+$ probiotic kefir & $1,88 \pm 1,12^{\mathrm{b}}$ & $-4,41 \pm 1,12^{\mathrm{b}}$ & $27,25 \pm 21,01^{b}$ \\
\hline HFHF+ synbiotic kefir & $3,84 \pm 0,89^{c}$ & $-2,44 \pm 0,89^{c}$ & $6,33 \pm 3,78^{b}$ \\
\hline $\mathrm{HFHF}+$ simvastatin & $2,7 \quad 7 \pm 1,97^{\mathrm{bc}}$ & $-3,51 \pm 1,99^{b c}$ & $19,79 \pm 17,89^{b}$ \\
\hline
\end{tabular}

Different letters in the same column indicate significant differences $(p<0,05)$

Normal control rats had an average $\Delta$ CT of $6.29, \Delta \Delta$ CT of 0.00 and an average of changes in gene expression of PPAR y2 $\left(2^{-\Delta \Delta C T}\right)$ of 1.00 .

Table 7 and Table 8 showed that the change in PPARy2 gene expression in liver tissue was higher than that in adipose tissue. In the rats fed a high-fructose and high-fat (HFHF) diet without kefir supplementation, the highest changes in PPAR gene expression $(p<0.05)$ were observed in both adipose and liver tissue.

\section{Immunohistochemical (IHC) of ß-cells}


The average number of Langerhans islets and insulin-producing beta cells with various treatments is shown in Table 9.

Table 9 The average number of Langerhans islets and insulin-positive ß-cells in rats with various treatments

\begin{tabular}{llcc}
\hline Treatments & Langerhans $^{\text {ns }}$ & \multicolumn{2}{c}{ Insulin-positive $ß$-cells $^{\text {ns }}$} \\
\hline Normal control & $3.04 \pm 0.78$ & 96.95 & \pm 94.19 \\
HFHF & $2.47 \pm 0.76$ & 46.08 & \pm 2.59 \\
HFHF+ probiotic kefir & $2.90 \pm 0.71$ & 71.74 & \pm 22.42 \\
HFHF+ synbiotic kefir & $3.55 \pm 0.65$ & 82.14 & \pm 45.27 \\
HFHF+ simvastatin & $3.05 \pm 0.82$ & 107.35 & \pm 79.95 \\
\hline
\end{tabular}

ns: non-significant

HFHF: high-fat high-fructose

The average number of Langerhans islets and insulin-producing beta cells in rats fed high fat and high fructose without kefir supplementation showed the lowest number, although not significantly different (Table 9).

Immunohistochemical (IHC) staining of pancreatic tissue showed that insulin-producing beta cells showed a brown color when using rat anti-insulin antibodies (Fig.1). Figure 7 shows that HFHF rats were rarely observed on Langerhans islets and had very weak intensity of IHC staining on insulin-producing beta cells, and there were few insulin-producing beta cells (Fig. 1), although the number of Langerhans islets and beta cells in all treatment groups was not significantly different (Table 9). Rats that received kefir treatment showed intense beta cell staining intensity as in negative control rats (normal normal rats). The HFHF rats given simvastatin showed less strong IHC staining intensity compared to kefir treatment.

\section{Discussion}

All rats fed a high fat and high fructose diets demonstrated a risk factor for metabolic syndrome with fasting blood glucose $>100 \mathrm{mg} / \mathrm{dL}$ [2]. After kefir treatments (probiotic and synbiotic kefir) in this study, there were no decrease in blood glucose in rats fed HFHF diet, except for simvastatin treatment. However, a konjac-derived glucomannan supplement ( $3.6 \mathrm{~g} /$ day) administered for 28 days reduced blood lipid and glucose levels by enhancing fecal excretion of neutral sterol and bile acid and alleviated the elevated glucose levels in hyperglycemic diabetic subjects [16]. In contrast to a previous study by [17], skim milk kefir given at a dose of $3.6 \mathrm{ml} /$ day for 4 weeks could significantly reduce blood glucose levels by 111.00 $\mathrm{mg} / \mathrm{dL}$. In the present study, the decrease in low blood glucose was possibly because synbiotic kefir was still not enough to play a role in reducing blood glucose in rats that consumed HFHF diets during the experiment. In the study by [17], diabetic rats were not fed a HFHF diet. The low dose of glucomannan in kefir and the difference in the conditions of the subjects may not cause a significant reduction in blood glucose levels.

The decrease in blood glucose by simvastatin treatment in this study is in accordance with a previous study by [18], in which mice fed a high-fat diet and treated with rosuvastatin showed lower blood glucose, which might be due to improved glucose uptake, but beta cell activity is inhibited through lowered insulin 
levels and inhibited $\mathrm{Ca}^{2+}$ signaling in beta cells, resulting in lowered insulin secretion. Duoble effects on glucose homeostasis by rosuvastatin are due to increased insulin sensitivity, while beta cell activity is inhibited. In another study by [19], glucose uptake in adipose tissue was upregulated in pravastatintreated mice fed a high fat/high sucrose diet and db/db mice. In contrast to studies by [20,21], simvastatins can increase the risk of T2DM, particularly in prediabetic subjects, due to hyperglycemia by impairing the function of islet $\beta$ cells and have a negative effect on glucose homeostasis, especially on fasting blood glucose levels. Atorvastatin at a high dose causes worsening of glycemic control in patients with DM [22]. According to [23], individual types of statins may have different effects on glucose metabolism. Based on the results of these studies, the possible effect of statins on blood glucose levels depends on the dose and type of statin and the condition of the subject used for the study.

Porang glucomannan added to kefir could improve glucose metabolism to reduce glycosylated hemoglobin. According to [24], the synergistic effects of these two components, probiotics and prebiotics, make it a more effective supplement than probiotics or prebiotics separately. In another study by [25], the fructose diet was rapidly metabolized by the liver, causing changes in carbohydrate and lipid metabolism as well as hepatic inflammation, which led to the development of hyperglycemia, insulin resistance, hyperinsulinemia, and hypertriglyceridemia as major risk factors for diabetes complications. The administration of a high fructose diet $(68.35 \%)$ over a long period of time can induce complications related to type 2 diabetes, namely, high blood glucose, glycosylated $\mathrm{HbA} 1 \mathrm{c}$, cholesterol, triglycerides and oxidative stress [26]. However, the results indicate that the administration of fermented milk containing the probiotic Lactobacillus rhamnosus GG (150 g/ $\mathrm{kg}$ standard diet) can reduce the increase in glycosylated hemoglobin (HbA1c) in rats induced by diabetes by feeding high fructose feeds [26]. Additionally, the 24 individuals with T2DM had significantly decreased HbA1c by $7.7 \%$ after glucomannan noodle intervention [10].

Probiotic and synbiotic kefir in the present study could maintain plasma FFA levels in HFHF rats. In a previous study, konjac-glucomannan supplementation (5\%) in baboons resulted in lower than baseline values for triglycerides and circulating free fatty acids after 9 weeks [27]. The lower dose of glucomannan from porang tuber in the present study compared to the previous study by [27] resulted in no decrease in plasma FFA. According to [28, 27], increased levels of circulating FFAs can stimulate fibrinogen synthesis in the liver. Elevated plasma fibrinogen is characteristic of insulin resistance in the liver (insulin may regulate the synthesis of fibribinogen). Glucomannan from konjac, which is fermented in the colon, can decrease FFA production, including propionate, leading to a decrease in fibrinogen synthesis. Therefore, colonie production and absorption of SCFAs (propionate) from soluble fiber may contribute to this fiber's metabolic effects [27]. The various physiological processes, including the control of lipolysis and lipogenesis in adipose tissue, inflammation, endocrine signaling and the composition and characteristics of cellular membranes may be affected by each kind of FFA. The progress of insulin resistance and coagulatory damage may result from the physiological changes caused by changed plasma FFA levels or profiles [29]. 
In the present study, porang glucomannan added to kefir can play a role in reducing the occurrence of inflammation through decreased production of pro-inflammatory cytokines in rats fed high-fat high fructose. The effect of soluble fiber in porang glucomannan on the improvement of metabolic disorders is in accordance with a previous study using chitosan fiber [30], which is given to rats with metabolic disorders (induced by diabetes), can improve insulin resistance and chronic inflammation through decreased lipid absorption and slowed absorption of glucose in the small intestine after eating, resulting in a decrease in hepatic lipids and weight of adipose tissue, and reduced plasma adipocytokine levels including leptin, TNFa and plasminogen activator inhibitor-1 (PAl-1).

In other study, supplementation with a combination of fiber (konjac glucomannan) and bacterial cellulose in high-fat diet-induced obesity in mice had a more positive effect on obesity-associated hepatic inflammation by reducing the levels of TNFa and IL- 6 and suppressing the protein expression of nuclear factor erythroid 2-related factor 2 ( $\mathrm{Nrf}-2$ ) in comparison with supplementation with bacterial cellulose or konjac glucomannan alone [31]. In addition, glucomannan and spirulina combination blocks detrimental effects promoted by hypercholesterolemic diets in Zucker rats, one of which could decrease plasma TNFa as one of an inflammation biomarkers [32].

Normally, PPARY2 is most abundantly expressed in adipocytes and plays major adipogenic and lipogenic roles in the tissue [33]. Because the rats in the present study received a high-fat and high-fructose diet, it was possible to cause fatty liver. According to $[34,35]$, in non-alcoholic fatty liver disease (NAFLD) patients and experimental animals there was an increase in the expression of PPARy in the liver. In addition, in mice fed a high-fat diet showed a high PPARy expression in the liver [36].

In the present study, the change in gene expression was the lowest in rat tissue that was treated with synbiotic kefir, although this difference was not significant compared to probiotic kefir treatment. It is possible that kefir-containing probiotics synergize with the prebiotic glucomannan and play a role in the downregulation of PPARy2 expression in white adipose and hepatic tissue. The result in the present study was similar to that of a previous study [37], in which mice fed a high-fat diet supplemented with $0.2 \%$ kefir powder for 8 weeks lowered PPARy gene expression in the epididymal fat. In another study, mice fed a high-fat diet and $1 \times 10^{7}$ or $1 \times 10^{9} \mathrm{CFU} /$ mice probiotic L. plantarum LG42 supplementation daily for 12 weeks reduced PPARy expression in adipose tissue [38]. Decreased levels of PPAR-y and GLUT4 mRNA after high fructose treatment were also enhanced by Lactobacillus reuteri GMNL-263 administration [39]. It was further emphasized by [31], besides reducing PPARy expression, the mixed bacterial cellulose and glucomannan from konjac also lowered the protein expression of PPARy by reducing the size of cells in the adipose tissue of high-fat diet-fed mice.

Consumption of dietary fibers, especially mixed bacterial cellulose/konjac glucomannan, resulted in an improved antioxidant defense system and reduced lipid peroxidation in the liver by increasing the activity of antioxidant enzymes and reducing the formation of malondialdehyde (MDA) in the liver. Moreover, supplementation with these fibers regulated the levels of leptin and adiponectin and inhibited the protein expression of PPARy by reducing the size of cells in the adipose tissue of high-fat diet-fed mice [31] 
The highest changes in PPAR y2 gene expression in both adipose and liver tissue of rats treated HFHF without kefir in the present study were in accordance with the results in a previous study [40], who found that the PPARy expression level was significantly higher in rats fed a high-fat diet than in rats fed a normal diet, which is mainly related to fat formation. PPARy2 is also expressed in the liver, specifically in hepatocytes, and its expression level positively correlates with fat accumulation induced by pathological conditions such as obesity and diabetes [33]

There was no change in the number of Langerhans islets and insulin-producing beta cells in all treatments, indicating that a high-fructose high-fat diet received during the experiment did not cause $\beta$ cell damage. This was also evidenced by unchanged average fasting blood glucose levels in HFHF rats before and after being treated with kefir (Table 2). According to [41], individuals with type 2 diabetes have decreased $\beta$-cell mass compared to nondiabetic individuals, and fasting blood glucose will increase if the volume (mass) of cells is less than the $1.1 \%$ threshold [42]. If it is below this threshold value, changes in insulin sensitivity and functional damage in insulin secretion will have a major impact on blood glucose. A high fat and high fructose diets in the present study had not yet led to diabetes but only caused prediabetes because blood glucose levels ranged from $100 \mathrm{mg} / \mathrm{dL}$ to $125 \mathrm{mg} / \mathrm{dL}$, which is at risk of becoming diabetic ( $\geq 126 \mathrm{mg} / \mathrm{dL}$ ), whereas normal blood glucose was $<100 \mathrm{mg} / \mathrm{dL}[43,44]$.

Immunohistochemical staining showed that rats fed HFHF diet without kefir addition had the weakest color intensity. However, rats fed HFHF diet with probiotic or synbiotic kefir showed a strong color intensity as in normal rats (Fig. 1). These result indicate that the probiotic microorganisms in kefir have an important role in improving insulin-producing $\beta$-cells. This was supported by a previous studies on diabetic rats treated with konjac extract (containing glucomannan) alone showed less strong in improving insulin-producing $\beta$-cells than the rats treated with combination of konjac and inulin extract [45].

\section{Conclusions}

The metabolic syndrome caused by the habit of consuming high-fat and high-fructose diets can be improved by consuming synbiotic kefir, through decreasing $\mathrm{HbA} 1 \mathrm{c}$, TNFa, and gene expression of PPARY2 and preventing the increase in FFA. Therefore, synbiotic kefir containing porang glucomannan is expected to be a suggestion for the food industry to develop synbiotic-based functional foods that have the potential to improve metabolic syndrome.

\section{Abbreviations}

HFHF: High-fat high-fructose; PPARY: Peroxisome proliferator activated receptor gamma; HbA1c: Hemoglobin A1c; TNFa: Tumor necrosis factor alpha; FFA: Free fatty acid; IHC: Immunohistochemical.

\section{Declarations}




\section{Ethics approval}

All treatments which given to animal experiments in this study were already approved by the Medical and Health Research Ethics Committee (MHREC), Faculty of Medicine Universitas Gadjah Mada, Indonesia (Approval number: KE/FK/95/EC/2015).

\section{Data Availability}

The original data used to present results of this study are available upon request.

\section{Conflict of Interest}

We certify that there is no conflict of interest with any financial, personal, or other relationships with other individu or organization associated with the material discussed in the manuscript.

\section{Authors' Contributions}

EH had a great contribution on research planning, discuss and review paper. $\mathrm{S}$ and $\mathrm{N}$ had a contribution to overall planning, preparing and performing this research.

\section{Consent for publication}

All authors support submission to this journal.

\section{Funding}

This research was funded by Directorate General of Higher Education, The Ministry of Research, Technology and Higher Education of the Republic of Indonesia in "Penelitian Unggulan Perguruan Tinggi" 2015 (No. 165/LPPM/2015).

\section{References}

1. Gregory JW. Prevention of obesity and metabolic syndrome in children. Front Endocrinol. 2019; 10(669): 1-9.

2. Botta M, Audano M, Sahebkar A, Sirtori CR, Mitro N, Ruscica M. PPAR agonists and metabolic syndrome: an established role? Int J MolSci. 2018;19(4):1-21.

3. Janani C, Kumari BDR. PPAR gamma gene - a review. Diabetes Metab Syndr. 2015;9(1):46-50.

4. Rosen ED, Sarraf P, Troy AE, Bradwin G, Moore K, Milstone DS, et al. PPARy is required for the differentiation of adipose tissue in vivo and in vitro. Mol Cell. 1999;4(4):611-7.

5. Feige JN, Gelman JN, Michalik L, Desvergne L, Wahli B. W. From molecular action to physiological outputs: peroxisome proliferator-activated receptors are nuclear receptors at the crossroads of key cellular functions. Prog Lipid Res. 2006;45(2):120-59. 
6. Choi JW, Kang HW, Lim WC, Kim MK, Lee IY, Cho HY. Kefir prevented excess fat accumulation in dietinduced obese mice. Biosci Biotechnol Biochem. 2017;81(5):958-65.

7. Pimenta FS, Luaces-Regueira M, Ton AMM, Campagnaro BP, Campos-Toimil M, Pereira TMC. et al. Mechanisms of action of kefir in chronic cardiovascular and metabolic diseases. Cell Physiol Biochem. 2018; 48(5): 1901-1914.

8. Harmayani E, Aprilia V, Marsono Y. Characterization of glucomannan from Amorphophallus oncophyllus and its prebiotic activity in vivo. Carbohydr Polym. 2014;112:475-9.

9. Al-Ghazzewi FH, Tester RF. Efficacy of cellulase and mannanase hydrolysates of konjac glucomannan to promote the growth of lactic acid bacteria. J Sci Food Agric. 2012;92(11):2394-6.

10. Cheang KU, Chen CM, Chen CYO, Liang FY, Shih CK, Li SC. Effects of glucomannan noodle on diabetes risk factors in patients with metabolic syndrome: a double-blinded, randomized crossover controlled trial. Food Nutr Res. 2017;5(8):622-8.

11. Otles S, Cagindi O. Kefir. A probiotic dairy-composition, nutritional and therapeutic aspects". Pak J Nutr. 2003;2(2):54-9.

12. Reeves PG, Neilsen FH, Fahey GC, JR. 1993. AIN-93 purified diets for laboratory rodents: final report of the American Institute of Nutrition ad hoc writing committee on the reformulation of the AIN-76A rodent diet. J Nutr. 1993;123(11): 1939-1951.

13. deCastro UGM. dos Santos RAS, Silva ME, de Lima WG, Campagnole-Santos MJ, Alzamora AC. Agedependent effect of high-fructose and high-fat diets on lipid metabolism and lipid accumulation in liver and kidney of rats. Lipids Health Dis. 2013, 12(136): 1-11.

14. Takahashi Y, Ide T. Effects of soy protein and isoflavone on hepatic fatty acid synthesis and oxidation and mRNA expression of uncoupling proteins and peroxisome proliferator-activated receptor $Y$ in adipose tissues of rats. J Nutr Biochem. 2008;19(10):682-93.

15. Livak KJ, Schmittgen TD. Analysis of relative gene expression data using real-time quantitative PCR and the 2(-Delta Delta C(T) method. Methods. 2001;25(4):402-8.

16. Chen HL, Sheu WHH, Tai TS, Liaw YP, Chen YC. Konjac supplement alleviated hypercholesterolemia and hyperglycemia in type 2 diabetic subjects-a randomized double-blind trial. J Am Coll Nutr. 2003;22(1):36-42.

17. Hadisaputro S, Djokomoeljanto RRJ, Judiono, Soesatyo MHNE. The effects of oral plain kefir supplementation on proinflammatory cytokine properties of the hyperglycemia Wistar rats induced by streptozotocin. Acta med Indones-The Indonesian Journal of Internal Medicine. 2012;44(2):1004.

18. Salunkhe VA, Mollet IG, Ofori JK, Malm HA, Esguerra JLS, Reinbothe TM, et al. Dual effect of rosuvastatin on glucose homeostasis through improved insulin sensitivity and reduced insulin secretion. EBioMedicine. 2016;10:185-94.

19. Takagi T, Matsuda M, Abe M, Kobayashi H, Fukuhara A, Komuro R, et al. Effect of pravastatin on the development of diabetes and adiponectin production. Atherosclerosis. 2008;196(1):114-21. 
20. Wang L, Duan G, Lu Y, Pang S, Huang X, Jiang Q, et al. The effect of simvastatin on glucose homeostasis in streptozotocin-induced type 2 diabetic rats. J Diabetes Res. 2013; 2013: 1-5.

21. van Stee MF, de Graaf AA, Groen AK. Actions of metformin and statins on lipid and glucose metabolism and possible benefit of combination therapy. Cardiovasc Diabetol. 2018;17(1):1-22.

22. Angelidi AM, Stambolliu E, Adamopoulou KI, Kousoulis AA. Is Atorvastatin associated with new onset diabetes or deterioration of glycemic control? Systematic review using data from 1.9 million patients. Int J Endocrinol. 2018; 2018: 1-18.

23. Kim J, Lee HS, Lee KY. Effect of statins on fasting glucose in non-diabetic individuals: nationwide population-based health examination in Korea. Cardiovasc Diabetol. 2018;17(1):1-11.

24. Schrezenmeir J, de Vrese M. Probiotics, prebiotics, and synbiotics-approaching a definition. Am J Clin Nutr. 2001;73(2 suppl):361s-364s.

25. Patel J, Matnor NA, lyer A, Brown L. A regenerative antioxidant protocol of vitamin e and a-lipoic acid ameliorates cardiovascular and metabolic changes in fructose-fed rats. Evid Based Complement Alternat Med. 2011; 2011: 1-8.

26. Sangwan S, Singh R. Therapeutic effects of probiotic fermented milk (LGG and L. casei NCDC 19) on progression of type 2 diabetes. J Innov Biol. 2014;1(2):078-83.

27. Venter CS, Vorster HH, Van Der Nest DG. Comparison between physiological effects of konjacglucomannan and propionate in baboons fed "Western" diets. J Nutr. 1990;120(9):1046-53.

28. Martin CR. Endocrine Physiology. Oxford: Oxford University Press; 1985.

29. Sobczak AIS, Blindauer CA, Stewart AJ. Changes in plasma free fatty acids associated with type-2 diabetes. Nutrients. 2019;11(9):1-42.

30. Chang HP, Yao HT, Chiang MT. Effects of high and low molecular weight chitosan on plasma cholesterol, glucose and adipocytokines in diabetic rats induced by streptozotocin and nicotinamide. J Food Drug Anal. 2012;20(3):661-7.

31. Lin D, Zhao Y, Lia W, Yang X. Enhanced anti-obesity effects of bacterial cellulose combined with konjac glucomannan in high-fat diet-fed C57BL/6J mice. Food Funct. 2018;9(10):5260-72.

32. Vázquez-Velasco M, González-Torres L, López-Gasco P, Bastida S, Benedí J, González-Muñoz MJ, et al. (2015). Effects of glucomannan/spirulina-surimi on liver oxidation and inflammation in Zucker rats fed atherogenic diets. J. Physiol. Biochem. 2015; 71(4): 611-622.

33. Lee YK, Park JE, Lee M, Hardwick JP. Hepatic lipid homeostasis by peroxisome proliferator-activated receptor gamma 2. Liver Research. 2018;2(4):209-15.

34. Skat-Rørdam J, Ipsen DH, Lykkesfeldt J, Tveden-Nyborg P. A role of peroxisome proliferator-activated receptor $Y$ in non-alcoholic fatty liver disease. Basic Clin Pharmacol Toxicol. 2019;124(5):528-37.

35. Liss KHH, Finck BN. PPARs and nonalcoholic fatty liver disease. Biochimie. 2017;136:65-74.

36. Lakhani HV, Sharma D, Dodrill1 MW, Nawab A, Sharma N, Cottrill CL, et al. Phenotypic alteration of hepatocytes in non-alcoholic fatty liver disease. Int. J. Med. Med. Sci. 2018; 15(14):1591-1599. 
37. Choi JW, Kang HW, Lim WC, Kim MK, Lee IY, Cho HY. Kefir prevented excess fat accumulation in dietinduced obese mice. Biosci Biotechnol Biochem. 2017;81(5):958-65.

38. Park JE, Oh SH, Cha YS. Lactobacillus plantarum LG42 isolated from gajami sik-hae decreases body and fat pad weights in diet-induced obese mice. J Appl Microbiol. 2014;116(1):145-56.

39. Hsieh, FC, Lee CL, Chai CY, Chen WT, Lu YC, Wu CS. Oral administration of Lactobacillus reuteri GMNL-263 improves insulin resistance and ameliorates hepatic steatosis in high fructose-fed rats. Nutr. Metab. 2013; 10(1): 1-14.

40. Mei L, Tang Y, Li M, Yang P, Liu Z, Yuan J, Zheng P. Co-Administration of cholesterol-lowering probiotics and anthraquinone from Cassia obtusifolia L. ameliorate non-alcoholic fatty liver. Plos One. 2015; 10(9): 1-16, 2015.

41. Linnemann AK, Baan M, Davis DB. Pancreatic $\beta$-cell proliferation in obesity. Adv Nutr. 2014;5(3):27888.

42. Ritzel RA, Butler AE, Rizza RA, Veldhuis JD, Butler PC. Relationship between beta-cell mass and fasting blood glucose concentration in humans. Diabetes Care. 2006;29(3):717-8.

43. Gholi Z, Heidari-Beni M, Feizi A, Iraj B, Askari G. The characteristics of pre-diabetic patients associated with body composition and cardiovascular disease risk factors in the Iranian population. J Res Med Sci. 2016;21(20):1-6.

44. Khan RMM, Chua ZJY, Tan JC, Yang Y, Liao Z, Zhao Y. From pre-diabetes to diabetes: diagnosis, treatments and translational research. Medicina. 2019;55(9):1-30.

45. Gao T, Jiao Y, Liu Y, Li T, Wang Z, Wang D. Protective effects of konjac and inulin extracts on type 1 and type 2 diabetes. J. Diabetes Res. 2019; 2019: 1-12.

\section{Figures}




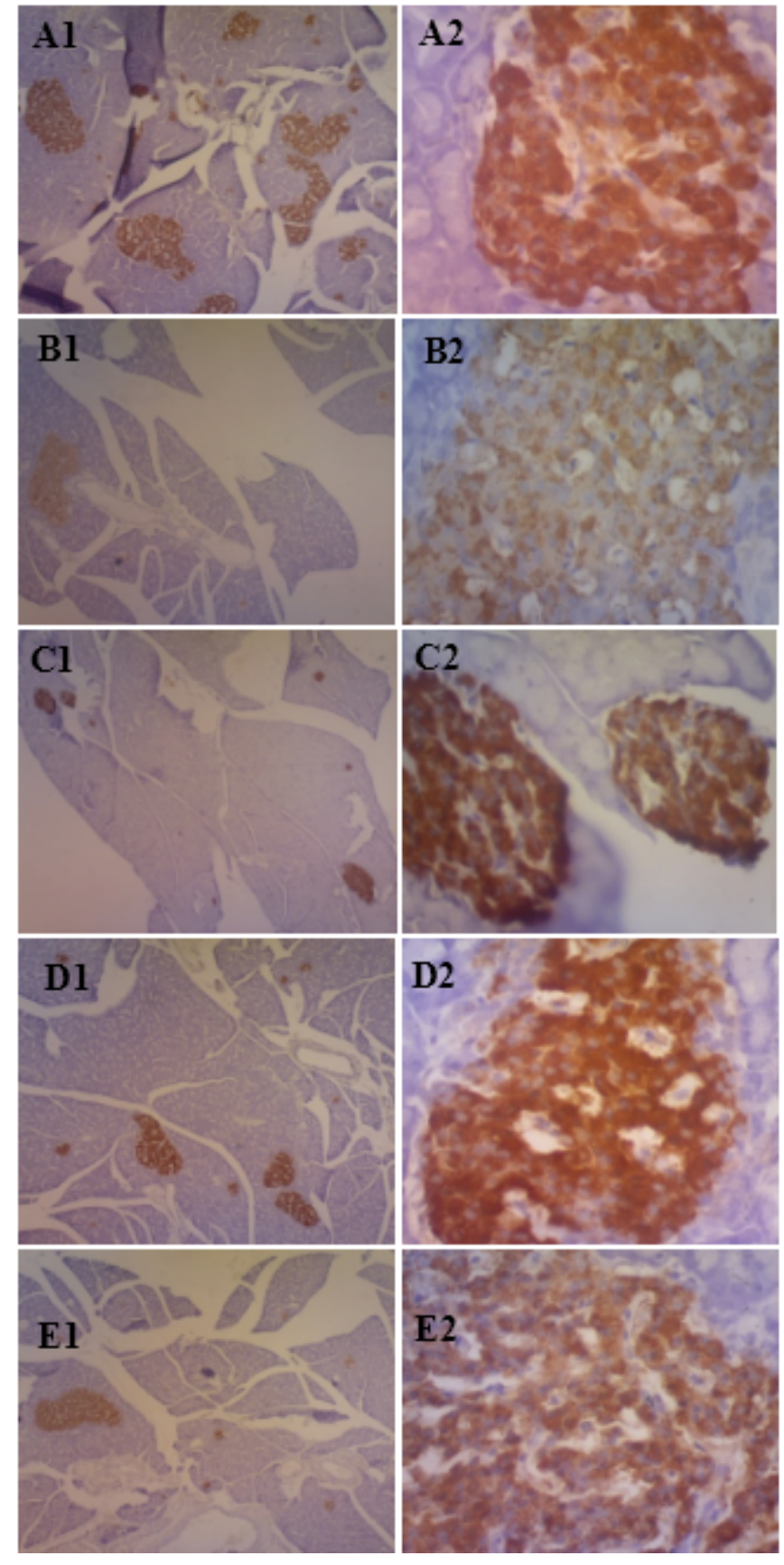

Figure 1

Immunohistochemistry of insulin-producing $\beta$-cells (brown colour). A: normal control; B: HFHF; C:

HFHF+probiotic kefir; D: HFHF+synbiotic kefir; E: HFHF+simvastatin. A1-E1: magnification 40x and A2-E2: magnification 400x. 